\title{
Fabric effectiveness on a batik shirt through design motifs
}

\author{
S. Yuningsih \& E.P. Hokianti \\ Telkom University, Bandung, Indonesia \\ C. Puspitasari \\ Universiti Sains Malaysia, Penang, Malaysia
}

\begin{abstract}
The development of batik-patterned shirts presents various forms and visualizations of various motifs, although the shirts' silhouettes do not show much change. The diversity of motif compositions on the batik-patterned shirts provides attractiveness and value. On the other hand, it has an impact, one of which is the production waste from batik cloth processing into clothing products. Seeing these problems, it is necessary to have a formulation or reference that underlies the design of an effective batik-patterned shirt product. The results of the literature study show that strategies for the effectiveness of use in the shirt production process can be carried out with a zerowaste approach that emphasizes the optimization and effectiveness of the material design process through an exploration of fabric dimensions and motif dimensions as well as synchronization of patterns and clothing design designs.
\end{abstract}

Keywords: effectiveness, batik, design, motif

\section{INTRODUCTION}

The fashion industry's development, especially apparel, is very rapid, marked by the emergence of innovative products and new fashion businesses that offer various products for consumer needs. The apparel industry is built on the participation of other industries moving from upstream to downstream. Ernawati (2015) states that the upstream apparel industry includes the fiber, spinning and yarn industry, knitting, printing, and finishing, and downstream the textile and textile products industry includes the apparel industry. In line with Ernawati et al. (2015) explained that there are three sectors of the textile industry: the upstream sector, which includes the fiber and yarn industry; the intermediate sector, which includes the fabric industry; and the downstream sector, which includes the apparel industry and the textile article industry. For this reason, the apparel industry is one of the mainstay commodities to drive the economy.

The apparel industry products are very diverse; one of the interesting ones is the batik shirt industry. Batik shirts have been around for a long time, around 1972, during Governor Ali Sadikin (Doellah 2002), and up to now can still survive through various obstacles and challenges of the times. Batik shirt now comes with a variety of creations in terms of diverse motifs and details, not even rare, unique, and unusual motifs are found (Yuningsih 2018). Basically, a batik-patterned shirt is product development in the batik-patterned fabric that adapts to modern needs (Suryana 2013). Batik cloth as the main raw material in batik shirt products, processed by designers to produce various shirt creations, both motifs, and details. However, the development of batik-patterned shirt products currently does not significantly change the shape and construction details of the shirt, so it can be said that the changes are very slight and do not change the shirt silhouette in general (Yuningsih 2018).

These conditions and the exploration of massive motifs on batik cloth material need to be responded positively. On the other hand, with the composition and dimensions of the increasingly diverse motifs on the fabric surface, new problems will arise, one of which is the synchronization 
of motifs on the shirt and the amount of fabric waste causing inefficient use of fabric raw materials. With the explanation above, the processing of apparel products in shirts with batik motifs can still be made efficient to reduce the amount of waste produced, one of which is through the design of efficient motif designs. For this reason, this research will discuss the efficiency of motif dimensions for batik shirts, so that the results of this study can reveal the composition and dimensions of motifs that are effective for production in the batik shirt industry. After this research is completed, it is expected that there is an efficient design or recommendation of motif dimensions and can be used as a reference in designing the development of motifs for apparel products, especially men's shirts made from batik motifs.

\section{METHOD}

In the above explanation, it was stated that the condition of the production design of a garment has potential waste, one of which is in the form of fabric leftover. Not all of these wastes can be utilized into products of economic value; for that, it is necessary to improve production material efficiency starting from the initial production process. This study aims to find the dimensions of motives effective in the production of men's batik-patterned shirts. In achieving this research, the authors researched qualitative methods through literature studies to find opportunities for effectiveness in clothing production and map the composition of the batik pattern in the shirt production process.

\section{RESULT AND DISCUSIONS}

As previously stated, the apparel industry has a broad scope of the industry, including the fiber and yarn processing industry, fabric processing, and apparel manufacturing (Zamroni and Ernawati 2015). Businesses in the field of apparel are owned by large-scale businesses and owned by businesses with small and medium scale. The batik shirt business can be mostly in the classification of Small and Medium Enterprises (SMEs) where the management is very diverse. The search for batik business constraints is known to be one of the big challenges in developing batik products related to the production costs and the differentiation of alternative products (Mangifera 2016). It was also conveyed by Nurainun and Rasyimah (2008), which explains that some things weaken the batik industry, namely high production costs, diminishing human resources, difficulties in obtaining raw materials at affordable prices, and the security situation.

Following the explanation above, a strategy is needed for the development of efficient batik products. In this research, the product is focused on batik shirts, so the production process does not stop only with batik cloth, but its processing to become ready-made clothing products. In this case, Fletcher (2008) explains in his book sustainability fashion, to start the production of ready to wear clothing starting from the time of processing the fiber to be marketed to consumers. This is related to the apparel production chain relating to broad industrial processes. To focus this research on achieving the formulation of the batik shirt production process's effectiveness, an approach is needed to obtain the effective formula in the production of batik patterned shirts, one of which is the concept of zero waste fashion.

Zero waste fashion is a method that aims to minimize waste and optimize fabric dimensions. According to Risannen and Almond (2013), the concept of minimizing waste in the production process can be done effectively by optimizing fabric dimensions. To optimize the fabric, it is necessary to design clothing patterns and design materials that are designed from the beginning effectively. This is far different from the concept of conventional clothing design, which still tends to emphasize the production process that stands alone in each process. In Risannen's explanation, most of the research was conducted on plain or striped cloth. In research, batik cloth has a pattern and structure of distinctive and unique motifs, so of course, a deep design and analysis process is needed.

With the above concept, the effectiveness of batik shirt production can be achieved through the design's effectiveness at the material design stage, where the fabric is planned to be more 

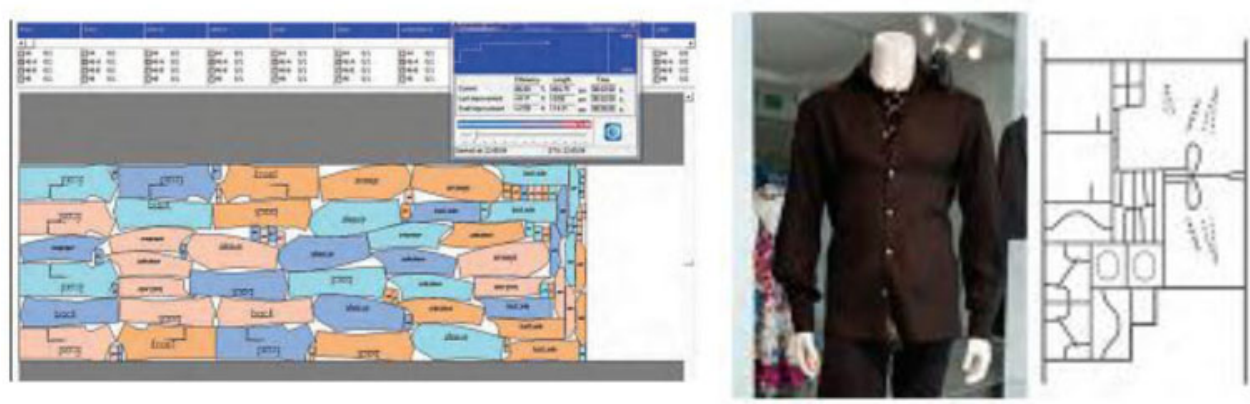

Figure 1. Layout design process (left: computerized system, right: zero waste method). (Source: Risannen and Almond 2013).
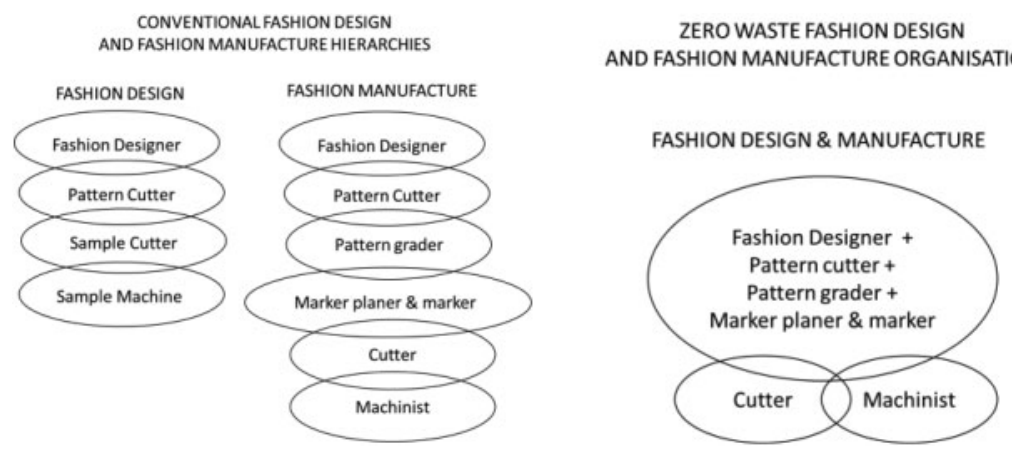

Figure 2. Comparison between conventional hierarchies and a new possibility for industry organization. (Source: Risannen and Almond 2013).

effective and still maintain the decorative elements of batik as its main characteristics. With this, it is necessary to experiment with placing the shirt pattern on batik cloth. Batik motifs with various visual dimensions and dimensions of different dimensions need to be analyzed to map the pattern of motifs on the fabric when the material design process can be known as effective dimensions of motifs for batik-patterned shirt products.

Batik shirts are familiar to people in Indonesia and even globally. For men, a batik shirt has become one of the dress choices in everyday life, both for formal or informal events. Basically, this patterned shirt is produced with the main material of the batik-patterned fabric; then it is produced into ready to wear clothing in the form of a shirt. To determine the effectiveness of this batik-patterned shirt, it is necessary to be traced through the pattern of developing batik motifs as the main material for shirt production.

One of the traditional fabrics known for their motive characteristics is batik; the unique technique and composition and its philosophical value make batik a traditional fabric that has distinctive characteristics compared to other traditional fabrics. The specificity of batik motifs can be known as one of them through the development of the motif. Batik motifs can be said as a framework of images that will realize batik as a whole (Susanto 1973).

To describe and map the patterns of developing batik motifs, it is necessary to know how the batik motifs are made and patterned in a fabric field. In this case, it is generally known that, based on Susanto (1973), it is also known that batik has a classification to distinguish the arrangement patterns, namely groups of geometric and non-geometric motifs. Geometric motifs are groups of motifs arranged with geometric forms or arranged in sloping lines that form rhombic lines. Examples of motifs classified in the geometric classification with a class of geometry are banji, ceplok, 
ganggong, and kawung, while the batik group with slanted lines, namely semen and udan liris. In this geometric group, the term raport is known, which is a part of the repeated motif vertically, horizontally, and diagonally in a field of batik cloth; in general, these report cards are rhombic or square in shape. Unlike geometric motifs, non-geometric motifs are groups of motifs arranged based on the forms of plants, animals, or nature. Even though this non-geometric pattern tends to be free, it still has a repetition of motifs in the fabric field. Examples of non-geometric motifs are found in semen and buketan terang bulan.

In his book, Susanto also explained the pattern of the development of geometric motifs consisting of four repetition patterns: (1) Tubruk, this pattern is a simple pattern where raport are arranged vertically and horizontally by shifting one step; (2) Onda-ende, this development pattern is arranged in a horizontal direction (left-to-right) shifted one step and vertically (face-to-back) shifted one step; (3) parang, raport arranged in an oblique direction in one direction, either just left or right only one step; and (4) Tubruk miring, this pattern is arranged in the direction of a slash, to the right or left by shifting one step. For non-geometric motifs in general, the arrangement patterns consist of batik motifs consisting of three parts: the main decorative motifs, fillers, and isen-isen (Doellah, 2002; Susanto, 1973). The motif patterns are arranged repeatedly in certain patterns in the fabric field so that the shape of the raport pattern is very dynamic in shape.

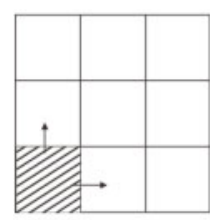

Tubruk

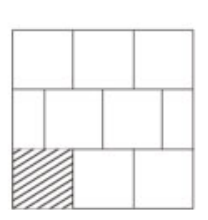

Onda-ende

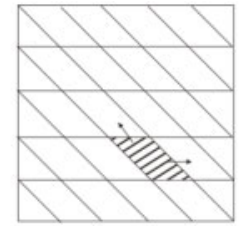

Parang

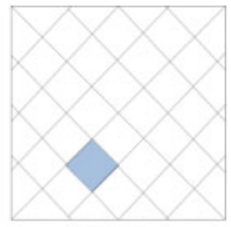

Tubruk miring

Figure 3. Raport/repetition of batik pattern. (Source: Susanto 1973)

In different literature also explained the pattern of repetition in the design of a motif. This was explained by Wilson (2001) and Kight (2011) that the basic structure of the repetition motif consists of (1) Straight repeat. This repetition pattern is the simplest repetition pattern, where the motif pattern is repeated to the top or bottom section repeatedly. (2) Half drop: For this repetition pattern, the vertical column's repetition pattern shifts half of the part to the bottom repeatedly. (3) Tile (or brick) repeat: This pattern of repetitive motifs is as simple as a brick placement pattern, where the motif is repeated half or one part in a horizontal direction. (4) Repeat mirrored vertically and horizontally: this motif is repeated by placing a mirror-like motif or facing off, repeated vertically and horizontally.

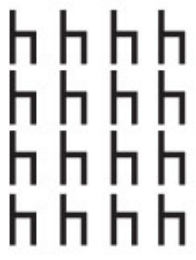

1) Straight repeat

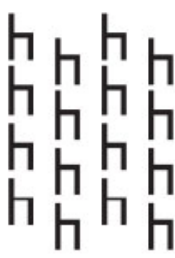

2) Half Drop

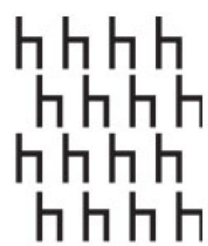

3) Tile (brick)repeat

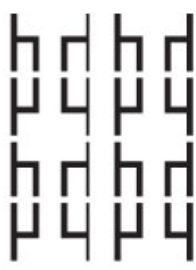

4) Repeat mirrored

Figure 4. Basic repeat structures. (Source: Wilson 2001).

With the description of the motif patterns above, the analysis of batik motifs in this study can be done by outlining the motifs' dimensions through the patterns of its development. For this reason, 
Table 1. Analysis of the batik motifs component.

\begin{tabular}{|c|c|c|c|c|c|}
\hline $\begin{array}{l}\text { Analysis of batik } \\
\text { motif patterns }\end{array}$ & Motif classification & Type of motif & $\begin{array}{l}\text { Batik motif } \\
\text { forms (raport } \\
\text { pattern) }\end{array}$ & $\begin{array}{l}\text { Raport system of } \\
\text { the motif }\end{array}$ & $\begin{array}{l}\text { Raport } \\
\text { dimension }\end{array}$ \\
\hline \multirow{2}{*}{$\begin{array}{l}\text { Classification of } \\
\text { motif types }\end{array}$} & a. Geometric & $\begin{array}{l}\text { Banji } \\
\text { Ceplok } \\
\text { Ganggong } \\
\text { Kawung }\end{array}$ & $\begin{array}{l}\text { Rhomb } \\
\text { Square }\end{array}$ & $\begin{array}{l}\text { Tubruk } \\
\text { Onda-ende } \\
\text { Parang/miring } \\
\text { Tubruk miring } \\
\text { atau }\end{array}$ & \multirow[t]{2}{*}{$\begin{array}{l}\text { In centimeter } \\
\text { or inches }\end{array}$} \\
\hline & b. Non-Geometric & $\begin{array}{l}\text { Semen } \\
\text { Buketan }\end{array}$ & $\begin{array}{l}\text { In accordance } \\
\text { with prepared } \\
\text { rapot cards }\end{array}$ & $\begin{array}{l}\text { Straight repeat } \\
\text { Half drop } \\
\text { Tile (or brick) } \\
\text { repeat } \\
\text { Repeat mirrored }\end{array}$ & \\
\hline
\end{tabular}

the formulation of the analysis of the development of batik motifs in the fabric field in this study refers to the above literature; see Table 1.

With the analysis above, the pattern of developing batik motifs can be known and mapped by elaborating the motifs, such as the classification of motifs, types of motifs, and the basic forms of motif patterns (report cards) developed. The basis of the compilation is the basis in preparing batik fabric motifs; if it refers to making clothes, the pattern of motif development is one part of the consideration in the effectiveness of the material when it will be produced.

\section{CONCLUSIONS}

After the analysis above, the fabric's effectiveness in the production of batik shirts can be achieved with a zero-waste fashion approach that emphasizes the effectiveness of fabric dimensions through clothing patterns on the fabric. In its application in the production of batik motifs, it is necessary to pay attention to the decorative elements of the batik motif based on consideration so that it requires an analysis of the composition and dimensions of the motif map motif patterns in the fabric field. Analysis of these motifs' composition or development can be done by classifying the motives, types of motives, report cards, repetition patterns, and report card dimensions. After knowing the formulation above, the next stage in the research still requires exploration and application of batik motifs in the field of fabric that is synchronized with clothing patterns through the material design process. This will be done in subsequent research reports to find out potential patterns and dimensions of motifs to be developed as a reference in designing efficient batik motif shirts.

\section{REFERENCES}

Doellah, H. Santosa. 2002. Batik Pengaruh Zaman Dan Lingkungan. Solo: Danar Hadi.

Fletcher, Kate. 2008. Earthscan Sustainable Fashion \& Textile: Design Journeys. UK: Earthscan.

Mangifera, Liana. 2016. Pengembangan Industri Kreatif Produk Batik Tulis Melalui Value Chain Analysis. The 3rd University Research Colloquium: 157-66.

Nurainun, Oleh, and Heriyana Rasyimah. 2008. Analisis Industri Batik di Indonesia Oleh: Nurainun, Heriyana Dan Rasyimah Fakultas Ekonomi Universitas Malikussaleh Banda Aceh. Fokus Ekonomi.

Risannen, Timo, and Kevin Almond. 2013. Zero-Waste Fashion Design: A Study at the Intersection of Cloth, Fashion Design and Pattern Cutting. Fashion Practice.

Suryana, Yan Yan. 2013. ITB Batik Digitalisasi Kreatif Motif Dalam Gaya Desain Dunia. Bandung: ITB. 
Susanto, S.K Sewan. 1973. Seni Kerajinan Batik Indonesia. Yogyakarta: Balai Pelatihan Batik dan Kerajinan Lembaga Penelitian dan Pendidikan Industri Departemen Perindustrian.

Wilson, Jacquie. 2001. Handbook of textile design Handbook of Textile Design. New York: Woodhead Publishing Ltd. \& CRC Press LLC.

Yuningsih, Sari. 2018. Kajian Elemen Estetik Kemeja Bermotif Batik Kontemporer (Studi Kasus Pada Desain Kemeja Bermotif Batik Danar Hadi). Bandung.

Zamroni, Salim, and Ernawati. 2015. Info Komoditi Pakaian Jadi Info Komoditi Pakaian Jadi. Jakarta: Badan pengkajian dan Pengembangan Kebijakan Perdagangan Kementrian Perdagangan RI dan Al Mawardi Prima. 